Integrated Water Resources Management Seminar, October 2008

\title{
HYDROLOGICAL PROPERTIES OF BRIBIN UNDERGROUND RIVER SYSTEM (Experience learned for Seropan River System Project)
}

\author{
by \\ Tjahyo Nugroho Adji and Sudarmadji \\ Faculty of Geography, Gadjah Mada University \\ Email: adji_tjahyo@geo.ugm.ac.id
}

\begin{abstract}
This paper is principally aimed to express some hydrological aspects regarding to the 2006-2007 time series investigation within Bribin River system. The concept of karst watershed and the Bribin System historical review is firstly presented in order to give the understandable viewpoint with reference to hydrological investigation conducted in this site. Afterwards, this paper illustrates some aspects of 2006-2007 Bribin System investigation such as site selection, equipments, measurements, and spatial-temporal results on discharge fluctuation, karst flow component ratio, and rainfall intensity. Lastly, this paper also evaluates the 2006-2007 investigation constriction and gives some recommendations related to the next Seropan River System study.
\end{abstract}

\section{INTRODUCTION}

In hydrology point of view, karst aquifer is characterized by the domination of underground stream that consequences to the lack of surface drainage pattern. This uniqueness is controlled by limestone geological structure (Blair, 2004). Structure is used here in the structural geologic sense and is concerned with the attitude and deformational effects of bedrock. Limestone near the surface has a propensity to be deformed by brittle fracture. As consequences, it forms complex joint sets is directly responsible for the secondary permeability or fracture required for the development of subsurface solution drainage.

For surface hydrologists, the "unidentified" fractured within subsurface system is considered as the primary problem to apply the watershed water balance equation. In addition, the concept of single water outlet and accurate recharge area are impracticable to be defined in karst area. Figure 1 is then illustrates the different concept between the surface and karst watershed area (Haryono and Adji, 2004)

According to Figure 1 (left) it appears that the boundary of the watershed is undoubtedly defined. In surface stream, the border line is characterized by the highest elevation topography, so that the entirely precipitation falls inside this boundary and flow out into only single outlet. On the other hand, we can not consider that the highest topography within karst conical as a catchment boundary since the flow direction within karst aquifer is largely controlled by the conduit pattern within conical. Also, it is impossible to find only single outlet or spring within karst limestone. In practical, some karst researches seem to define the area of karst watershed, especially within insoluble dolomite karst aquifer like occur in Central Europe. However, in Bribin area where the calcite limestone is very soluble and also supported by the occurrence of million of joint and fracture systems (present by tectonic force), it seem not achievable to exactly define the catchment area of Bribin or Seropan. However, approaching topographical aspect such as elevation, general slope of 
karst area, the lineament density and direction is believed to assist the better understanding of Gunung Sewu karst aquifer system.

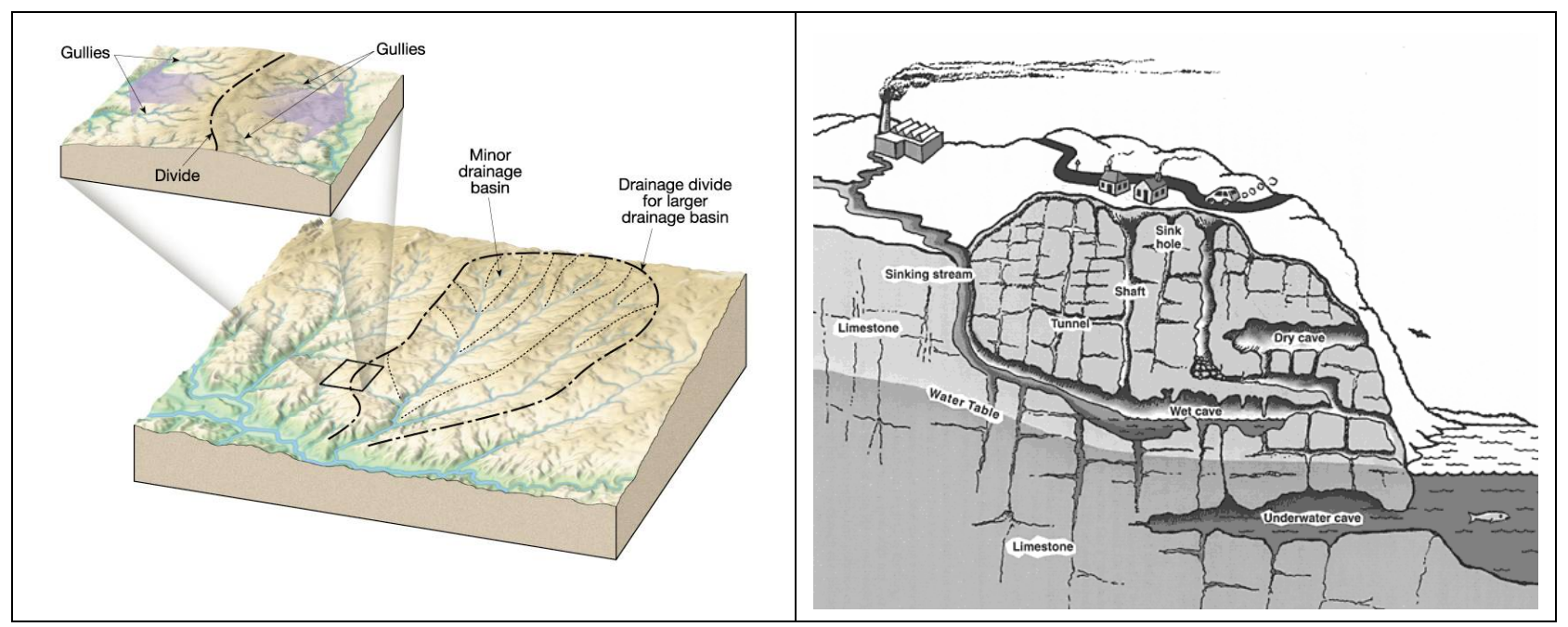

Figure 1 Watershed of surface drainage area (left) and unknown watershed in sub-surface drainage area

\section{HISTORICAL REVIEW OF BRIBIN HYDROLOGICAL SYSTEM INVESTIGATION 1 MACDONALD AND PARTNERS (1981-1984).}

The initial investigation in regard to hydrologic system in karst Gunung Sewu is conducted by MacDonald and Partners (1984). In this research, they divided the source of subsurface karst groundwater into two groups, which are: (1) eight allogenic river sink from Wonosari Plateau System, and only three of these are perennial: Kali Tegoan, Kali Serpeng, and Kali Suci (Figure 2) and (2) autogenic source, mostly coming from rainfall within conical karst area that subsequently reaches conduit system by karst processes (Adji and Haryono, 1999). In addition, they also describe the distribution and contribution of the majority of cave sites to comprise sinkhole shaft systems in conical karst area. To define the flow regime of the conduit system, this research carries out water tracing experiment that mainly using fluorescent dyes. The result of water tracing is then listed in Table 1After conduction tracer test investigation, they subsequently compose the North-East Gunungsewu hydrologic map that commonly used by many Indonesian stakeholders until this moment. However, according to our opinion, it seems that MacDonald and Partners sometimes locates the mistaken geographic position as well as the name in terms of the cave and surface streams within the map. Also, MacDonald and Partners doesn't find the location of Seropan Cave that actually performs the significant discharge of underground river. As consequences, this map pays no attention to the occurrence of Seropan point that may cause to the mistake interpretation of underground river pathway. 


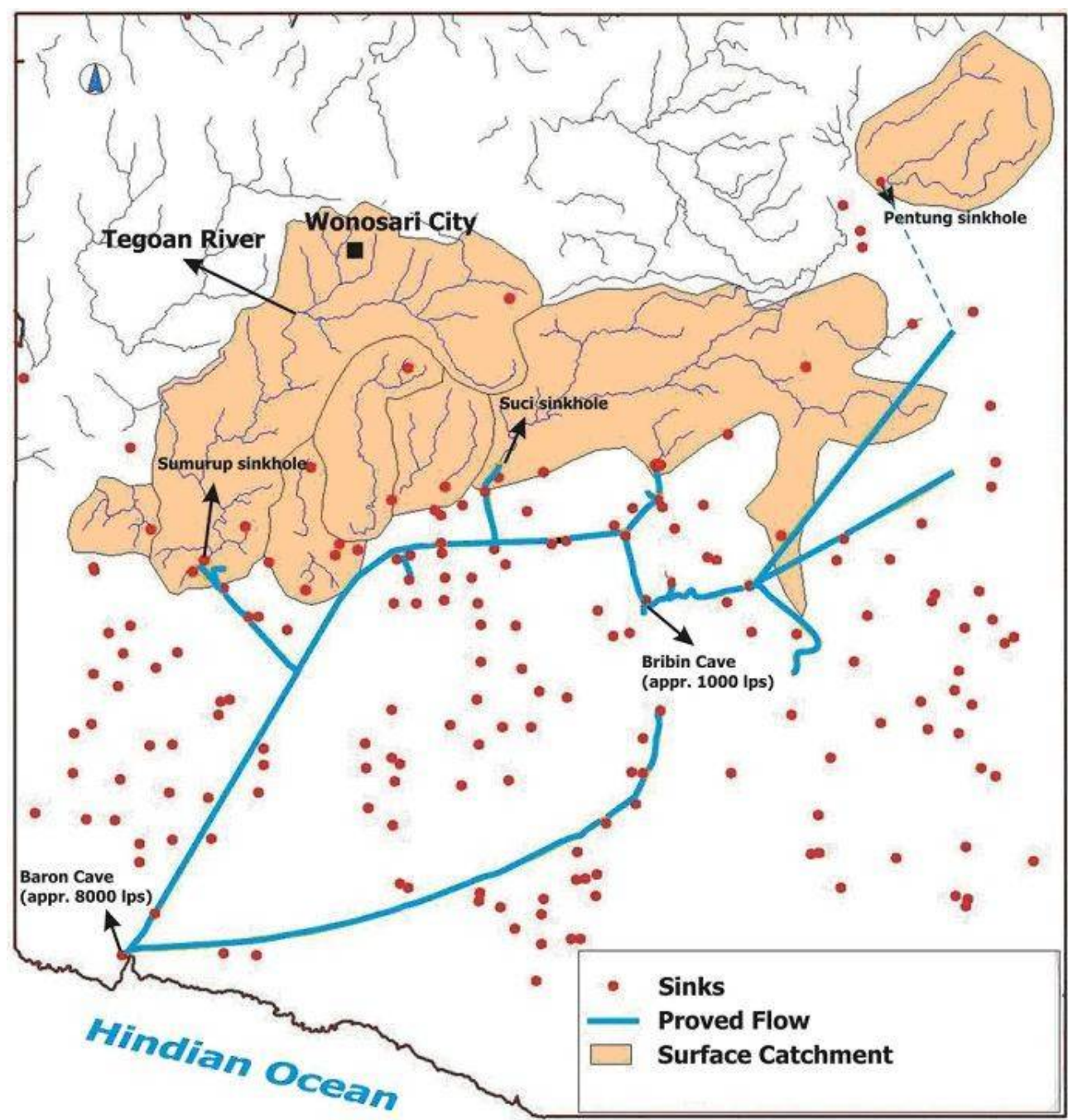

Figure 2. Possible recharge of Bribin-Baron Underground Water System

\section{FAKULTAS KEHUTANAN UGM (1993)}

This research is actually aimed to give the perspective related to the conservation of Bribin surface catchment area in terms of re-vegetation action. Consequently, the team decides to firstly introduce the exact area of the watershed since this research requires the total area for plantation in $\mathrm{km}^{2}$. Afterward, geomorphological approach is conducted to define the boundary of the watershed as illustrated in Figure 3. In addition, this research also investigates the underground river system that related to main Bribin River. 39 caves were mapped and tracer technique is also carried out. 
Table 1 Result of Gunungsewu Karst Water Tracing Experiment by MacDonald and Partners (1984)

\begin{tabular}{|c|c|c|c|c|}
\hline Input site & Date & Output site & $\begin{array}{c}\text { Travel time } \\
\text { (days) }\end{array}$ & $\begin{array}{c}\text { Velocity } \\
\text { (km/day) }\end{array}$ \\
\hline Kali Tegoan & $5 / 8 / 82$ & Baron & 4 & 2.8 \\
\hline Gua Bribin & $5 / 8 / 82$ & Baron & 14 & 15 \\
\hline Kali Suci & $12 / 8 / 82$ & Baron & 7 & 2.7 \\
\hline Gua Buri Omah & $27 / 8 / 82$ & L. Grubug & $<20$ hour & $>12$ \\
& & Baron & $6-7$ & 2.6 \\
\hline Gua Gilap & $24 / 8 / 82$ & Gua Bribin & $>5$ & $<.3$ \\
\hline Gua J omblang Banyu & $24 / 8 / 82$ & Gua Bribin & $<5$ & $<19$ \\
& & G, Ngreneng & $<6$ & - \\
\hline Goa Sodong Dadapayu & $27 / 8 / 82$ & Gua Bribin & $2-3$ & 15 \\
& & Gua Ngreneng & $<3$ & $>3.0$ \\
\hline Gua Toto & $12 / 8 / 82$ & Luweng Ceblok & - & - \\
\hline L. Buhputih & $19 / 8 / 82$ & Baron & $15-16$ & 10 \\
\hline Gua Sodong Mudal & $25 / 8 / 82$ & Pracimantoro & $>6$ & - \\
\hline
\end{tabular}

Concerning to the cave field mapping and tracer techniques, then this research produces the new map of Bribin river hydrographic network. This research believes that Bribin River is starting from the sinkhole of Petung River in Tambakromo. Then, the path of Bribin River is: Petung RiverSinkhole Sawah Ombo - Luweng Jomblangan - Gua Gilap - Luweng Jomblang Banyu - Luweng Jurangjero - Bribin and confirmes that this underground water course also has some leakages, there are: Bribin-Ngreneng and Jomblang Banyu-Ngreneng, as also illustrated in Figure 3. The weak points of this research, in our opinion are: (1) the watershed boundary that simply based on topographical features and (2) no explanation in regard to the tracer test investigation. However, some researches refer to this watershed boundary such as Adji and Nurjani (1999), Adji (2005), and Suryanta (2001).

\section{6-2007 RESEARCH BY FACULTY OF GEOGRAPHY, GMU}

A recent research is conducted by the author of this paper applying the hydrographic network and the watershed border line that is based on the combination of the last two researches. However, some modification is made according to the author's professional judgment. This research is a part of PhD thesis that is entitled: "Temporal and Spatial Variation of Hydrogeochemistry and Karst Flow to Characterize Karst Dynamic System (KDS) Behavior along Bribin River", which is aimed:

1 To understand the spatial-temporal variation and the proportion of karst flow components (diffuse/fissure vs. conduit flow) along Bribin River

2. To define the hydrogeochemical variation and to find the correlation between hydrogeochemical and the proportion of karst flow component

3. To measure the agressivity and dissolution rate of along Bribin River

4. To describe the behavior and correlation of $\mathrm{KDS}$ components $\left(\mathrm{CO}_{2}-\mathrm{H}_{2} \mathrm{O}-\mathrm{CaCO}_{3}\right)$ along Bribin River 


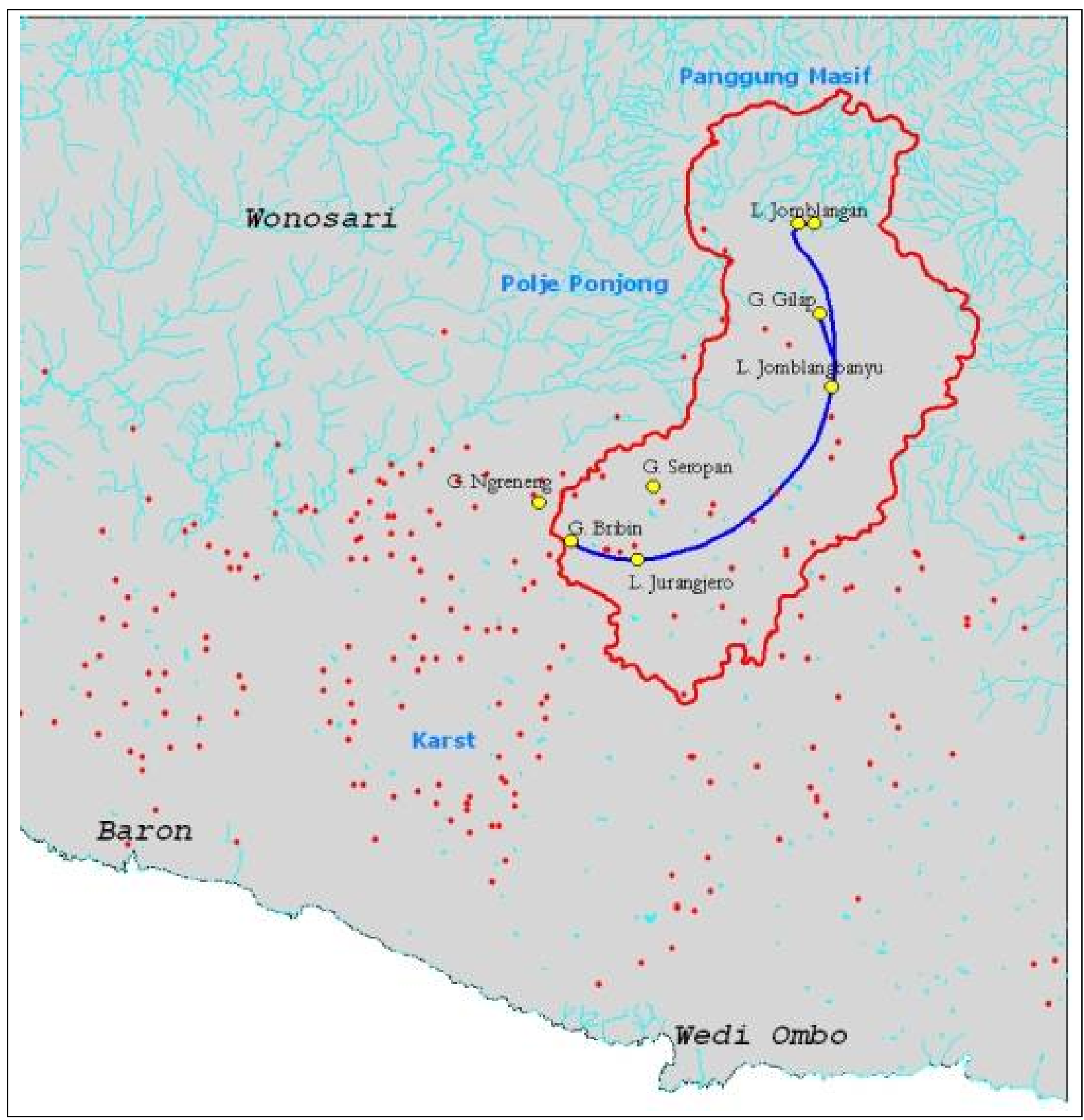

Figure 3. Watershed model by Fakultas Kehutanan (1993)

\section{a. Karst watershed and hydrological properties equipment distribution}

The northern and western part border lines of the watershed used in this research are still identical with the previous one (Figure 3), since the surface topographical phenomena is reasonable to separate groundwater district. The northern part is bounded by volcanic "Panggung Massif" rock topography; while the western part is bounded by the occurrence of large depression known as "Polje Ponjong" that lies continue to Wonosari Basin (Srijono and Aldila, 2006). However, we can not accept the southern and eastern watershed boundary since there is no obvious topography to separate water district. Then, the watershed model is illustrated in Figure 4. 


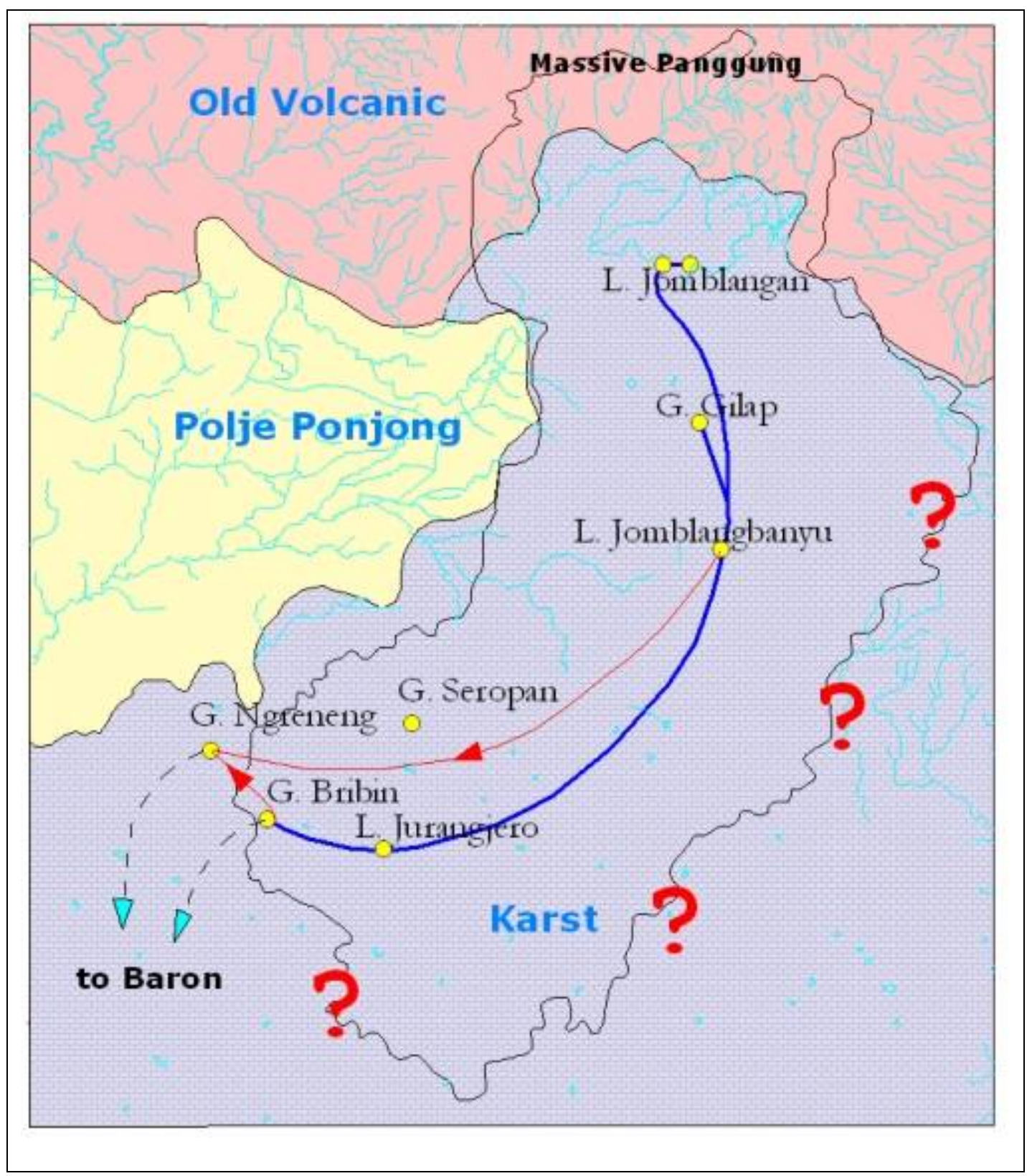

Figure 4. Watershed used in 2006-2007 research

After defining the watershed, 3 rainfall and 3 water level data logger are installed within the watershed with some consideration, i.e.: water level data logger are put along Bribin River (upper lower) with possible accessibility to be easily recorder (example: we avoid to install water level data logger in J omblang Banyu and Jurang J ero cave since the accessibility is very difficult-take 2 days and 7 hours to achieve those river points, respectively); rainfall data logger is put representing upper part, middle part and lower part of the catchment, so that it will be reasonable to construct area rainfall by Thiessen or Isohyetal Method. The distribution of equipment in the research area is showed in Figure 5. 


\section{b. Water Level Fluctuation and Stage-Discharge Rating Curve along Bribin River}

For figuring time-series water level fluctuation along Bribin River, the installation of water level recording station is needed. Figure 6 illustrated the example of water level data logger and its installation within Gilap, Ngreneng and Bribin Cave.

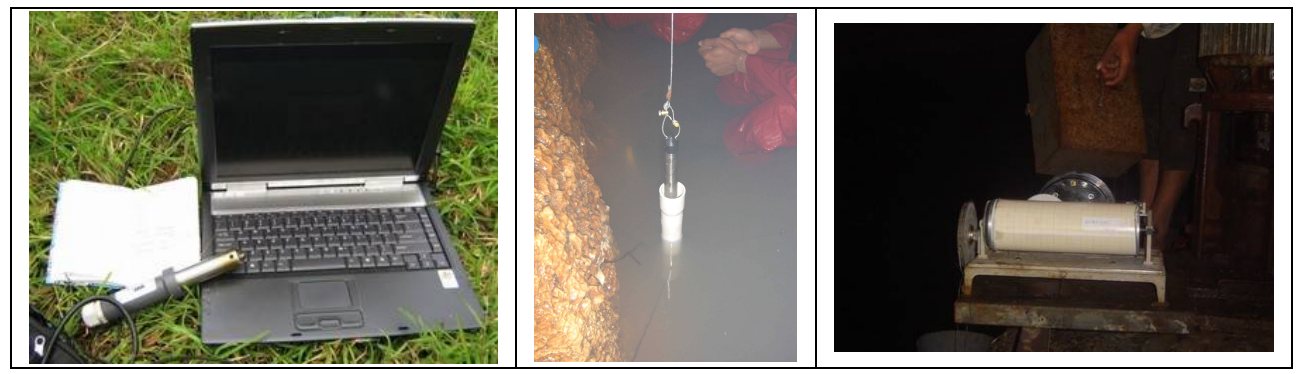

Figure 6. Water level data logger in Gilap Cave (left), installation data logger in Ngreneng Cave (middle), and Automatic Water Level Recorder -AWLR in Bribin (right)

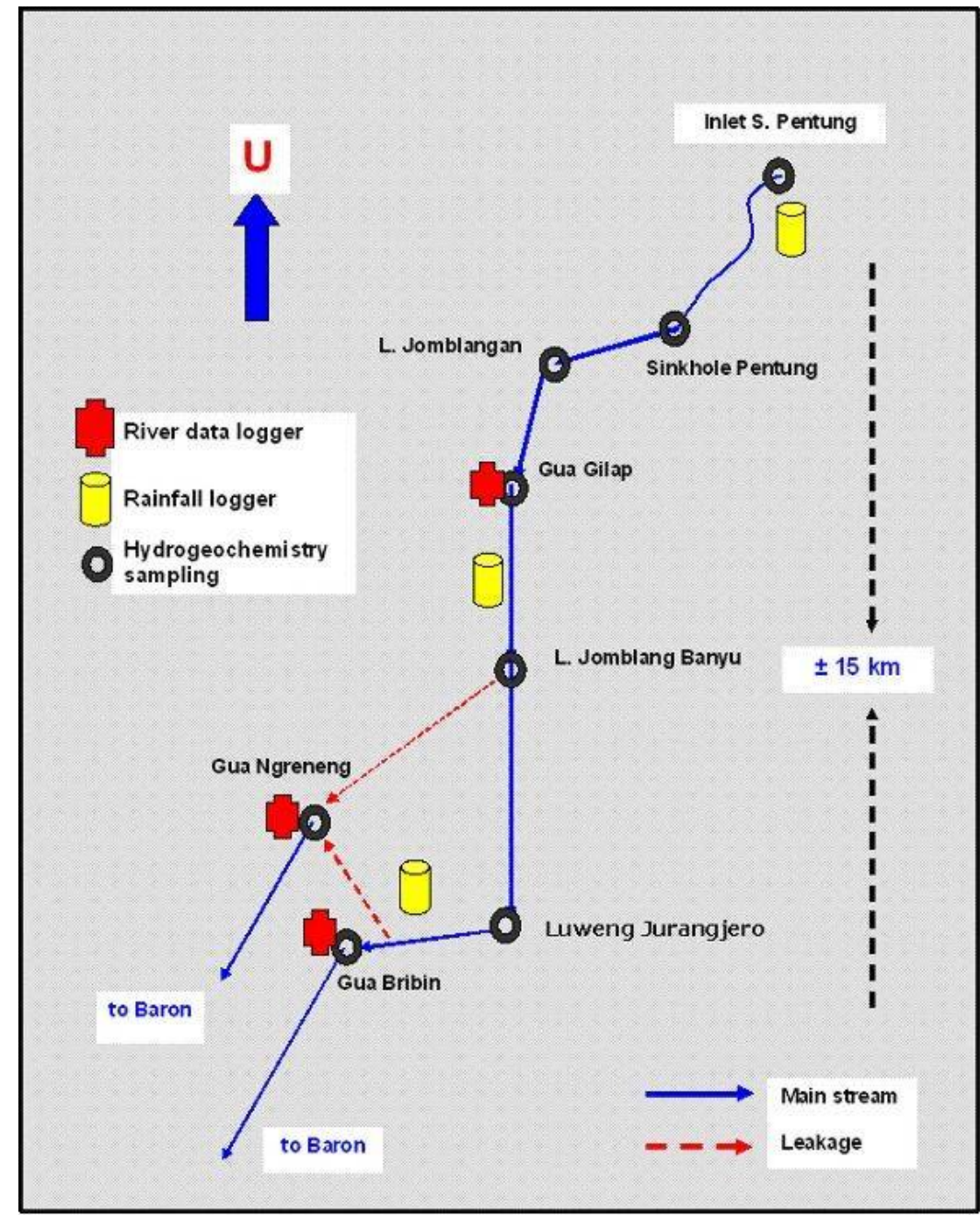

Figure 5. Equipment and sampling distribution 
Together with the water level recording, discharge measurement also conducted in every situation to construct the relationship between water level $(\mathrm{m})$ and river discharge, so that the stage-discharge rating curve is achieved as showed in Figure 7.

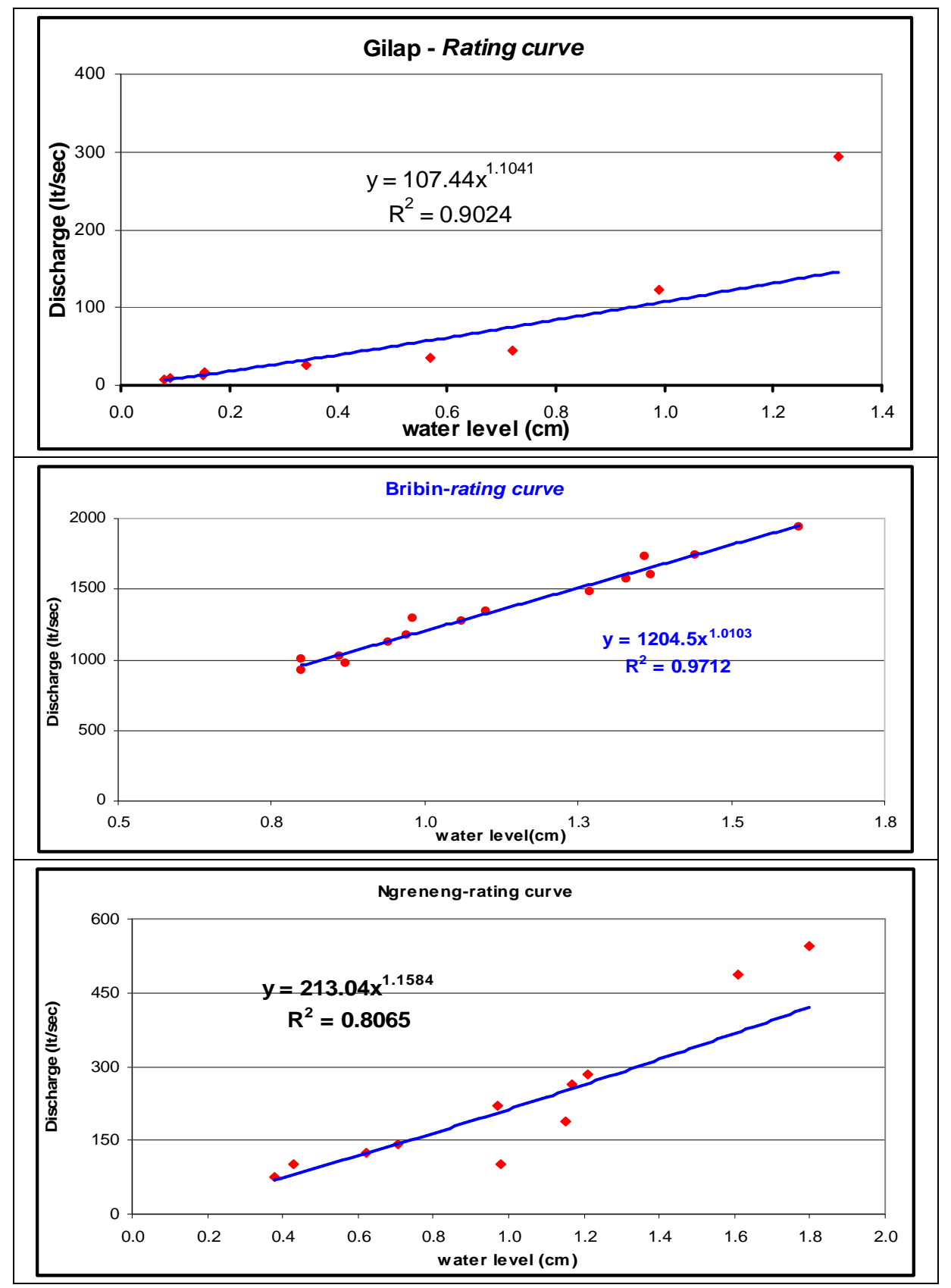

Figure 7. Water level-discharge relationship in Gilap-upper catchment, Bribin-lower catchment, and Ngreneng-leakage

\section{c. one-year discharge fluctuation}

After achieving the rating curves in each discharge measurement stations along Bribin River, then the time series in every station can be figured out, as mentioned below. 


\section{Gilap Cave}

Gilap cave represents the upper part of the Bribin watershed. The water in this cave is of reasonable quality and for much of the year below the entrance carries a flow of more than 20 litre/sec. However, within the late dry season the discharge showed only around 3 liter/sec (MacDonald and Partners, 1984). The measurement from 1May 2007 to 30 April 2007 shows that the minimum discharge occurs in 7 December 2006 by approximately 6 litre/sec, whereas maximum flood event discharged confirmed in 23 March 2007 by about 380 litre/sec. The full one-year discharge fluctuation illustrated in Figure 8.

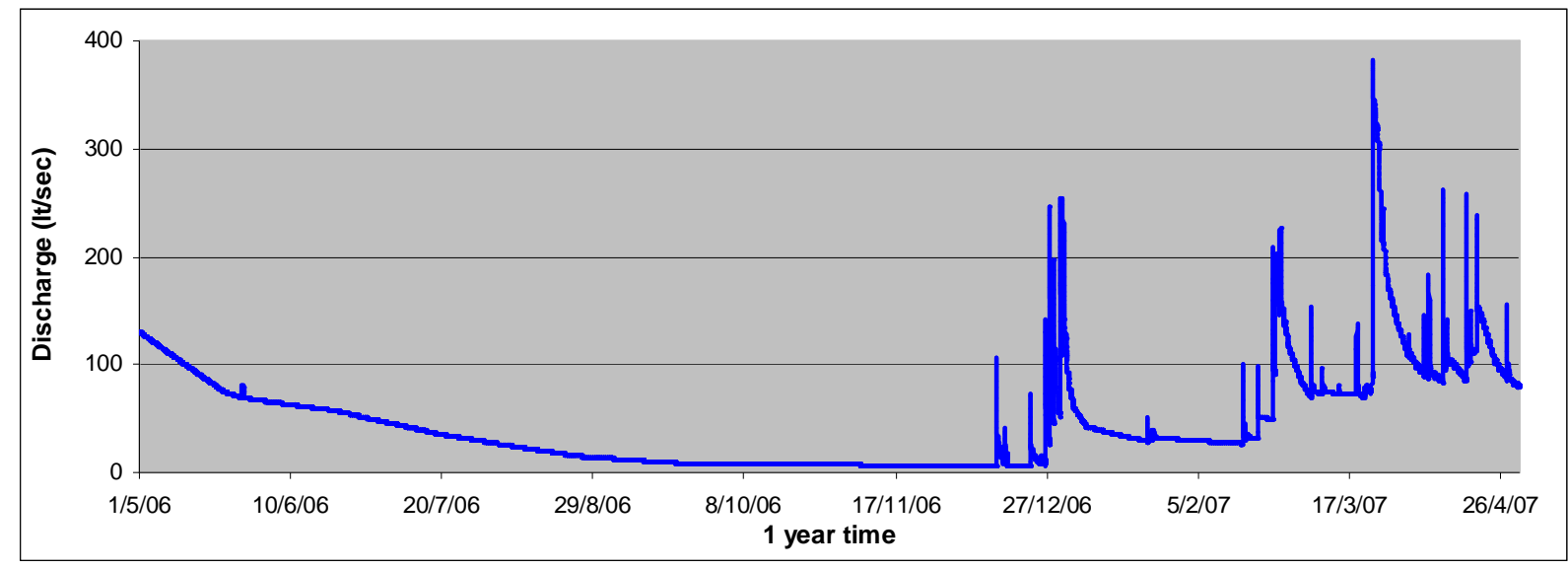

Figure 8. one-year discharge fluctuation in G. Gilap-the upper part of Bribin catchment

\section{Bribin Cave}

The AWLR and HOBO water level data logger installed in the old dam of Bribin cave to represent the discharge fluctuation of the lower part of the catchment. The measurement from 1 May 2007 to 30 April 2007 shows that the minimum discharge occurs in 4 December 2006 by approximately $\mathbf{1 6 3 0}$ litre/sec, while maximum flood event discharged confirmed in 23 March 2007 by about $\mathbf{2 5 2 0}$ litre/sec. The full 1year discharge fluctuation is then illustrated in Figure 9.

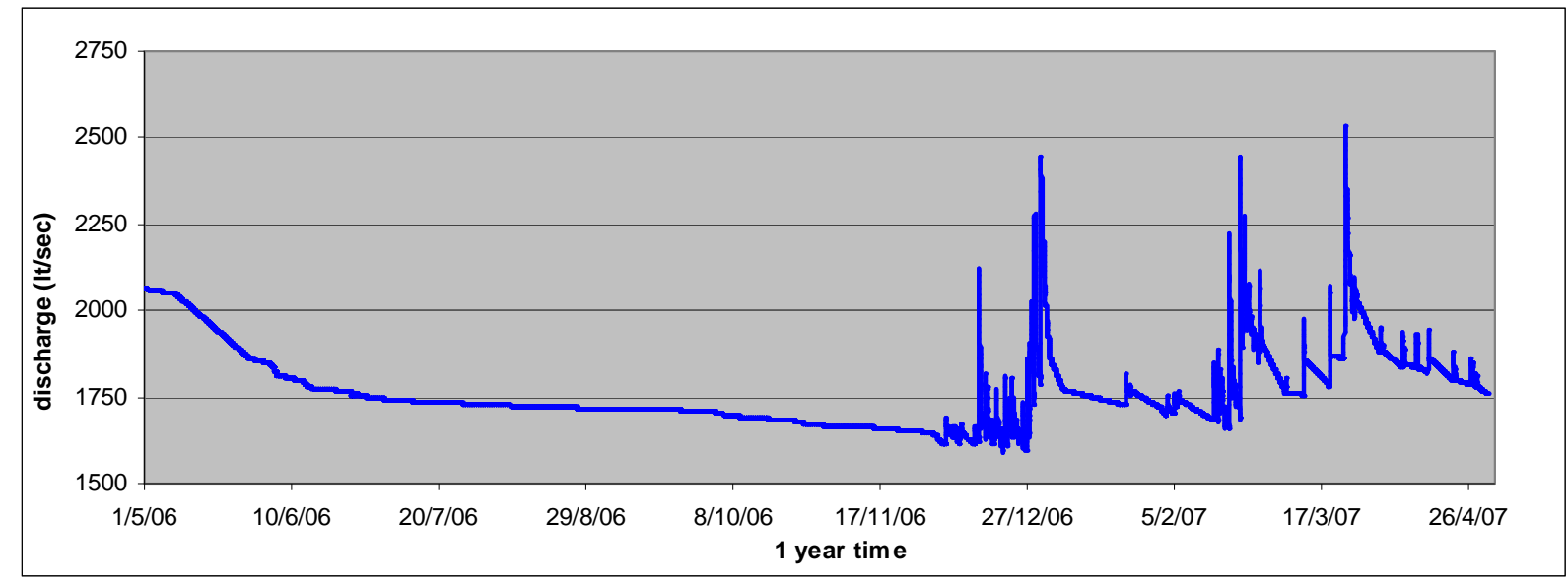

Figure 9. one-year discharge fluctuation in G. Bribin, the lower part of Bribin catchment 


\section{Ngreneng Cave}

Ngreneng Cave represents the leakage discharge of Bribin River. According to MacDonald and Partners (1984), the discharge of Ngreneng cave is proved as a leakage from Bribin and Jomblang Banyu caves. The measurement from 1 May 2007 to 30 April 2007 shows that the minimum discharge occurs in 12 December 2006 by approximately 60 litre/sec, while maximum flood event discharged confirmed in $23 \mathrm{March} 2007$ by about $\mathbf{1 9 0 0}$ litre/sec. The full 1year discharge fluctuation is then illustrated in Figure 10.

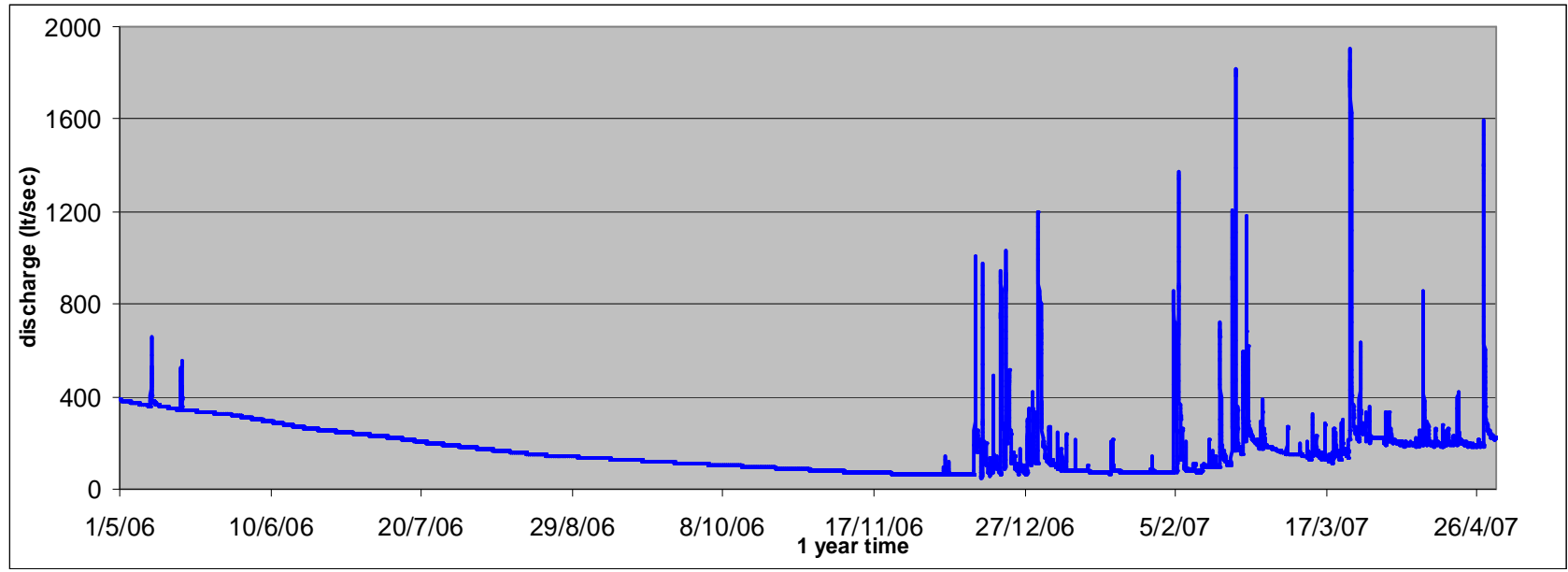

Figure 10. one-year discharge fluctuation within Bribin River Leakage (Ngreneng Cave)

\section{d. the proportion of flow component along Bribin River}

As clarified by White (1993), Ford and Williams (1992), Smart and Hobbes (1986) as well as Gillieson (1996), principally the flow component within karst underground river is divided into 2 main components, they are: conduit flow and diffuse flow. Conduit flow dominates the subsurface river within the flood event and related to the number of the sinkholes at karst surface, while diffuse flow (or known as percolated water by cavers) is infiltrated very slowly through the surface (epikarst) zone and reaches the underground river in the course of drips or seepages. The significant of diffuse flow is very important since it is the only component that contributes to the river during dry period, because no rainfall means no conduit flow to occur. The term of diffuse flow is identical to the term of baseflow in surface hydrology.

The diffuse flow separation and the calculation of conduit flow proportion in this study is approached by automated base flow separation by digital filtering method (Eckhardt, 2005). The key of this method is to calculate the digital filtering in every cave based on the constant recession within the one-year hydrograph and the definition of baseflow indices (BFI) within karst aquifer, by formula:

$$
q_{b(i)}=\frac{\left(1-B F I_{\max }\right) a q_{b(i-1)}+(1-a) B F I_{\text {max }} q_{i}}{1-a B F I_{\text {max }}}
$$

where $q_{b(i)}$ is the baseflow event in $i, q_{b(i-1)}$ is the baseflow in $i-1, q_{i}$ total discharge in time $i, a$ is the constant recession and $\mathrm{BFI}_{\max }$ is maximum baseflow (obtained by table/references). Next, Figure 11 shows the baseflow separation in Gilap, Bribin, and Ngreneng Cave, and the comparison of diffuse flow percentage between wet and dry season is showed in Table 2. 


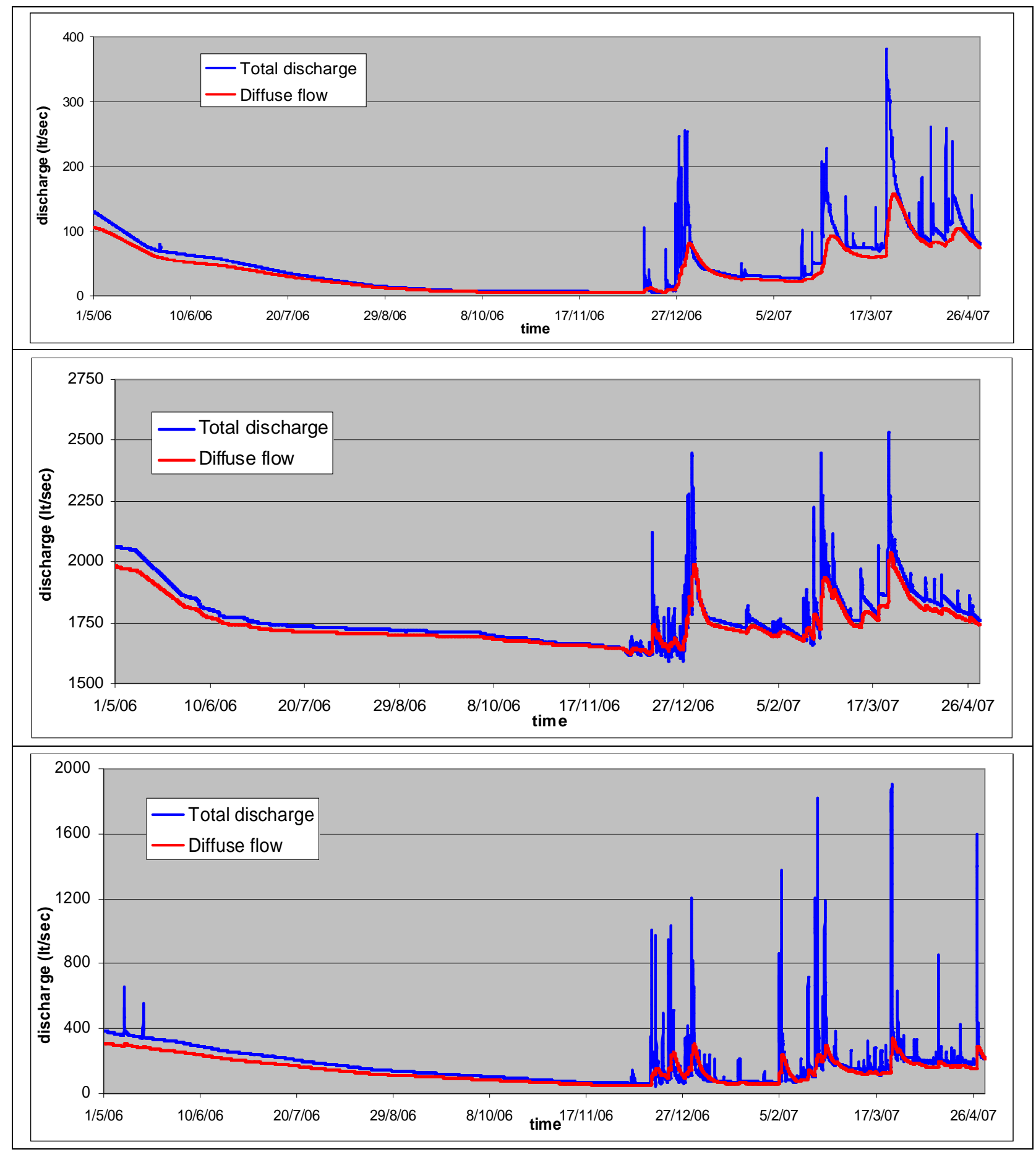

Figure 11 Conduit and Diffuse Flow Separation using digital filtering within Gilap-upper catchment-top, Bribinlower catchment, and Ngreneng-leakage-bottom 
Table 2. The average of wet and dry season contribution of diffuse flow along Bribin River

\begin{tabular}{|l|l|l|c|c|}
\hline \multirow{2}{*}{ No } & \multicolumn{2}{|c|}{ Caves } & \multirow{2}{*}{ Position } & \multicolumn{2}{c|}{ \%of diffuse/baseflow } \\
\cline { 3 - 5 } & & & Dry season & Wet season \\
\hline 1 & Gilap & Upper catchment & $85.50 \%$ & $85.03 \%$ \\
\hline 2 & Bribin & Lower catchment & $98.70 \%$ & $98.16 \%$ \\
\hline 3 & Ngreneng & Leakage & $8143 \%$ & $92.48 \%$ \\
\hline
\end{tabular}

Note: the number of percentage of diffuse flow component is calculated (in average) in one-period of wet/dry season. The calculation in every month or between rainfall events will give very different value. For instance, within the Gilap peak flood event in 23 March 2007, the diffuse flow proportion is only $\mathbf{2 3 . 1 2} \%$

\section{e. Rainfall intensity}

Rainfall is the foremost input for hydrological processes within karst aquifer. Subsequently, 3 rainfall data logger is installed that represent the upper, middle, and lower part of the catchment as the distribution is showed in Figure 5. Next, Figure 12 illustrated the type of the rainfall data logger that installed within Bribin watershed.

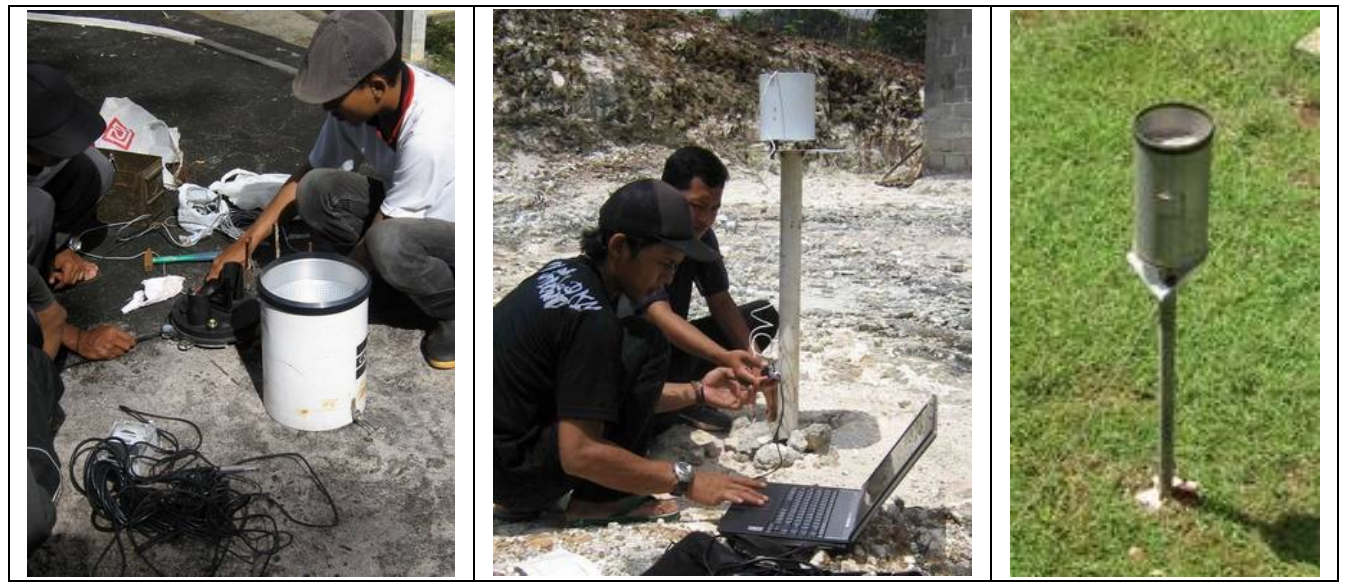

Figure 12. Castella automatic (upper catchment-left); Onset-HOBO RG3M (middle catchment); semi automatic rain gauge (lower catchment -right)

The monthly rainfall intensity within Bribin watershed is then showed in Table 3. According to Table 3, it clearly seems that the upper part of the catchment experiences the biggest intensity of rainfall that achieves almost $4000 \mathrm{~mm} / \mathrm{year}$. Geomorphologically, this condition is due to the orographic rainfall since the elevation of Tambakromo station is extremely highest compare to that Karangasem and Dadapayu stations. Based on this data, then we can construct the isohyetal area of rainfall, but we can not present in this paper since the process is still in progress 
Table 3. M onthly Rainfall Intensity within Bribin Watershed (May 2006-April 2007)

\begin{tabular}{|c|c|c|c|c|c|c|c|c|c|c|c|c|c|c|}
\hline \multirow{2}{*}{$\begin{array}{l}\text { Rainfall } \\
\text { Station }\end{array}$} & \multirow{2}{*}{ Position } & \multicolumn{13}{|c|}{ Intensity (mm) } \\
\hline & & May & Jun & Jul & Aug & Sep & Oct & Nov & Dec & Jan & Feb & Mar & Apr & Total \\
\hline Tambakromo & Upper & 151 & 3.5 & 23.5 & 0 & 0 & 0 & 67 & 1001 & 245.5 & 673.5 & 706.5 & 625.5 & 3497 \\
\hline Karangasem & Middle & 56 & 0 & 7 & 8.5 & 0 & 0 & 8.75 & 692 & 94.2 & 425.8 & 3318 & 197 & 1821 \\
\hline Dadapayu & Lower & 68 & 7.5 & 8.5 & 10 & 0 & 0 & 17.5 & 604 & 31 & 176.5 & 325.5 & 1111 & 1359 \\
\hline
\end{tabular}

The duration of rainfall recording within Bribin watershed performs the same period as the recording of water level fluctuation (1 May 2006-30 April 2007) with the purpose of applying rainfallrunoff respond modelling along Bribin River. However, the rainfall-runoff responds modelling is still being conducted (in process), so we can not describe the result in this paper.

\section{SCIENTIFIC CHANCE FOR NEXT SEROPAN SYSTEM INVESTIGATION}

After conducting the investigation for one year representing the hydrologic condition of Bribin River, we understand that there are some weaknesses regarding to the availability of dataset. Also, we propose some suggestion regarding to the next Seropan watershed and subsurface hydrological network. There are:

- The minimum number of rainfall gauge data logger installed is only 3 which represent the upper, middle, and lower catchment. In our point of view, at least 9 rainfall stations should be installed.

- The watershed boundary is constructed by only considering topographical features, so that, the eastern and southern border line can not be defined. We propose to put some rain gauges within the eastern part of the watershed, and records only 1or 2 times during storms event to apply rainfall-runoff responds. Then the border line may be roughly defined.

- The " missing" point of SEROPAN by MacDonald and Partners (1984) is very disturbing. If we look at Figure 4. It clearly appears that the leakage from L. Jomblang Banyu should flow through G. Seropan before reaching G. Ngreneng. So that, we propose to conduct "new" tracer studies to fully describe the hydrologic system of Bribin and Seropan System.

- We do not install any water level data logger in L. Jomblang Banyu (the consideration is due to the very long and difficult access to reach the river point of this luweng). However, by this point, in our opinion, is the "KEY" to define the whole watercourse and network in Bribin River and its vicinity since according to the tracer test conducted by MacDonald and Partners (1984), the river water from this point goes to Ngreneng and Bribin. Consequently, we propose to install water level data logger in this point in order to confirm this fact and to find the relationship with Seropan System by using rainfall-runoff respond model. Then, we need also to install 1 water level data logger in Seropan point.

- Until this moment, there is no information regarding to the local or regional base level (above mean sea level) of subsurface water course in Bribin watershed. So that, the calculation and the construction of local base level should be carried out previous to the tracer studies because the mistaken of local base level definition will give the wrong decision of input or output point of tracer studies. This method to define the local and 
regional water base level is very simply to be conducted because we already have the detail cave map by MacDonald and Partners (1984) or other researches.

- Due to our intention that the application of water-cheap-microhydro energy in Bribin and Seropan should be sustain in very extended time, so that the understanding of Bribin and Seropan hydrological system as well as the recording of yearly fluctuation of diffuse flow must be seriously undertaken within this site.

\section{REFERENCES}

Adji T.N. dan Nurjani, E.., 1999. Optimasi Airtanah Karst Sebagai Pemasok Air Domestik Pada Kawasan Kritis Air di Gunung Kidul, Laporan Penelitian, Fakultas Geografi UGM (tidak dipublikasikan)

Adji, T.N. and Haryono, E., 1999. Konflik Antara Pemanfaatan Batugamping dan Konservasi Sumberdaya Air Das Bribin di Wilayah Karst Gunung Sewu, Makalah Lokakarya Nasional Menuju Pengelolaan Sumberdaya Wilayah Berbasis Ekosistem Untuk Mereduksi Konflik Antar Daerah, Yogjakarta, , Fakultas Geografi, Universitas Gadjah M ada, September 1999

Adji, T.N., 2005, Agresivitas Airtanah Karst Sungai Bawah Tanah Bribin, Gunung Sewu, Indonesian Cave and Karst J ournal, Vol. 1No1, HIKESPI

Adji, T.N., Haryono, E., Woro, S, 1999, Kawasan Karst dan Prospek Pengembangannya di Indonesia, Seminar PIT IGI di Universitas Indonesia, 26-27 Oktober 1999

Blair,R.W., 2004, Karst Landforms and Lakes, Geomorphology from Space, NASA, USA

Eckhardt K, 2005. How to construct recursive digital filters for baseflow separation. Hydrological Processes 19, 507-515.

Fakultas Kehutanan, 1993. Penyusunan Arahan Konservasi Tanah dan Air di Daerah Tangkapan Air Gua Bribin Kabupaten Gunung Kidul DIY. Kerjasama antara Dinas Kehutanan DIY - Fakultas Kehutanan UGM Yogyakarta

Ford, D. and Williams, P. 1992. Karst Geomorphology and Hydrology, Chapman and Hall, London

Gillieson, D., 1996, Caves: Processes, Development, and Management, Blackw ell, Oxford

Haryono, E. dan Adji, T.N. 2004. Geomorfologi dan Hidrologi Karst. Yogyakarta: Kelompok Studi Karst, Fakultas Geografi, Universitas Gadjah Mada

MacDonalds and Partners. 1984. Greater Yogyakarta - Groundwater Resources Study. Vol 3C: Cave Survey. Yogyakarta, Directorate General of Water Resources Development Project (P2AT)

Smart, P.L. and Hobbes, S.L., 1986. Characteristics of Carbonate Aquifers: A conceptual basis. In Proceedings, Environmental Problem in Karst Terrains and Their Solution. Bowling Green, KY: National Well Water Association, 1-4

Srijono and Aldila, 2006, Geogenesis Polje-Purba Ponjong, Kabupaten Gunungkidul, Daerah Istimewa Yogyakarta, Indonesian Cave and Karst J ournal, Vol. 2 Nol, HIKESPI

Suryanta, G., 2001, Kajian Karakteristik Hidrograf Satuan Daerah Karst Gunung Kidul (Studi Kasus: Daerah Tangkapan Air Sungai Bawahtanah Bribin, Kabupaten Gunung Kidul, Propinsi DIY), Skripsi Sarjana, Fakultas Geografi, UGM , Yogyakarta

White, W.B., 1993. Analysis of Karst Aquifer. In:Alley, W.M. (editor), Regional Groundwater Quality. Van Nostrand Reinhold, New York 